\title{
DANISH GEOGRAPHY TEACHERS' PERCEPTIONS OF THEIR OWN TEACHING PROFESSIONALISM ACCORDING TO CLIMATE CHANGE
}

\author{
Søren Witzel Clausen
}

Institut for Uddannelse og Pædagogik, Aarhus Universitet, Debmark • witzel@edu.au.dk

\begin{abstract}
This paper reports from research examining eight Geography teachers' own perceptions of their teaching professionalism, understood as Pedagogical Content Knowledge (PCK), in relation to the topic of climate change. Apparently, Geography teachers with a strong academic profile in Physical Geography and natural science are more familiar to teach the sub-subject of weather formation in connection to climatic change, than Geography teachers with a strong academic profile in Human Geography and social science. The teachers orientated against Human Geography put emphasis on the more problem-oriented/discursive aspects of teaching climate change, some of them neglecting parts of the curriculum focused on weather formation. Most of the interviewed Geography teachers emphasize the collegial cooperation with science colleagues e.g. during professional development activities, when reflecting on their own teaching professionalism.
\end{abstract}

\section{Indledning}

Undervisningsfagligheden blandt skolelærere i geografi er et relativt ubeskrevet forskningsfelt inden for den fagdidaktiske forskning i Danmark. En stor del af de danske geografilærere har ikke en formel undervisningskompetence (se tabel 1) i geografifaget, samtidig med at faget er et af de mindste skolefag i folkeskolens fagrække (Nikolajsen \& Larsen, 2013). På den anden side kan de unge, i faget geografi, arbejde med vedkommende, aktuelle og spændende emner og problemstillinger som eleverne møder i deres hverdag. Det kan være i form af emner og problemstillinger om befolkningsmigrationer, knaphed på ressourcer, vulkanudbrud, klimaændringer, ulighed i verden m.m.., de meget ofte har hørt omtalt i medierne, og som kan være med til at øge deres omverdensforståelse (Møller, 2001) og danne dem som samfundsborgere. Det er derfor ikke helt uvæsentligt hvorledes undervisningen i geografifaget varetages og udvikles.

I nærværende artikel gives et billede af 8 geografilæreres egen forståelse af deres undervisningsfaglighed, forstået som Pedagogical Content Knowledge (PCK), set i forhold til emnet vejr og klimaændringer. I den danske folkeskole tilhører geografifaget den naturfaglige fagrække og omfatter både naturgeografi og kulturgeografi. Emnet klimaændringer er valgt, da det er en global, aktuel problemstilling og det indholdsmæssigt integrerer flere elementer fra både naturgeografien og kulturgeografien. Ud fra et didaktisk perspektiv lægger emnet også op til at man i undervisningen både sætter fokus på regionale problemstillinger, f.eks. den intensiverede forekomst af oversvømmelser i Holland og Bangladesh, samtidig med at man i undervisningen også arbejder med den systematiske geografi; f.eks. i forhold til vejrets dannelse. Emnet klimaændringer kan således være medierende for geografilærernes syn på deres undervisningsfaglighed inden for et centralt emne i faget. 


\section{Undervisningsfaglighed og PCK begrebet}

I 1986 introducerede Lee Shulman begrebet Pedagogical Content Knowledge (PCK), som omfattede: "the most useful forms of representation of those ideas, the most powerful analogies, illustrations, examples, explanations, and demonstrations - in a word, the ways of representing and formulating the subject that make it comprehensible to others. ... the teacher must have at hand a veritable armamentarium of alternative forms of representation... PCK also includes an understanding of what makes the learning of specific topics easy or difficult: the conceptions and preconceptions that students of different ages and backgrounds bring with them..." (Shulman, 1986, 9). Siden da, har der været mange fortolkninger af især PCK begrebets indholdsområder og afgrænsning. Således skriver Sandra Abell (2007, s.1123): "Research on science teacher PCK resides in a formative phase, where researchers continue to define the terms and methods that guide their work". Flere forskere lader således PCK begrebet være en overordnet kategori i forhold til underkategorierne: Subject Matter Knowledge (SMK), Pedagogical Knowledge (PK) og knowledge of Context (KofC) (Grossman, 1990; Cochran, King, \& DeRuiter; 1991; Magnusson, Krajcik, \& Korko; 1999; Abell, 2007). Det efterlader altså en diskussion om de forskellige komponenters indhold og hierarkiske status, som dog ikke vil blive udfoldet yderligere i denne artikel. Nedenstående figur 1 illustrerer overordnet hvorledes PCK begrebet konstitueres ifølge Sandra Abell (2007).

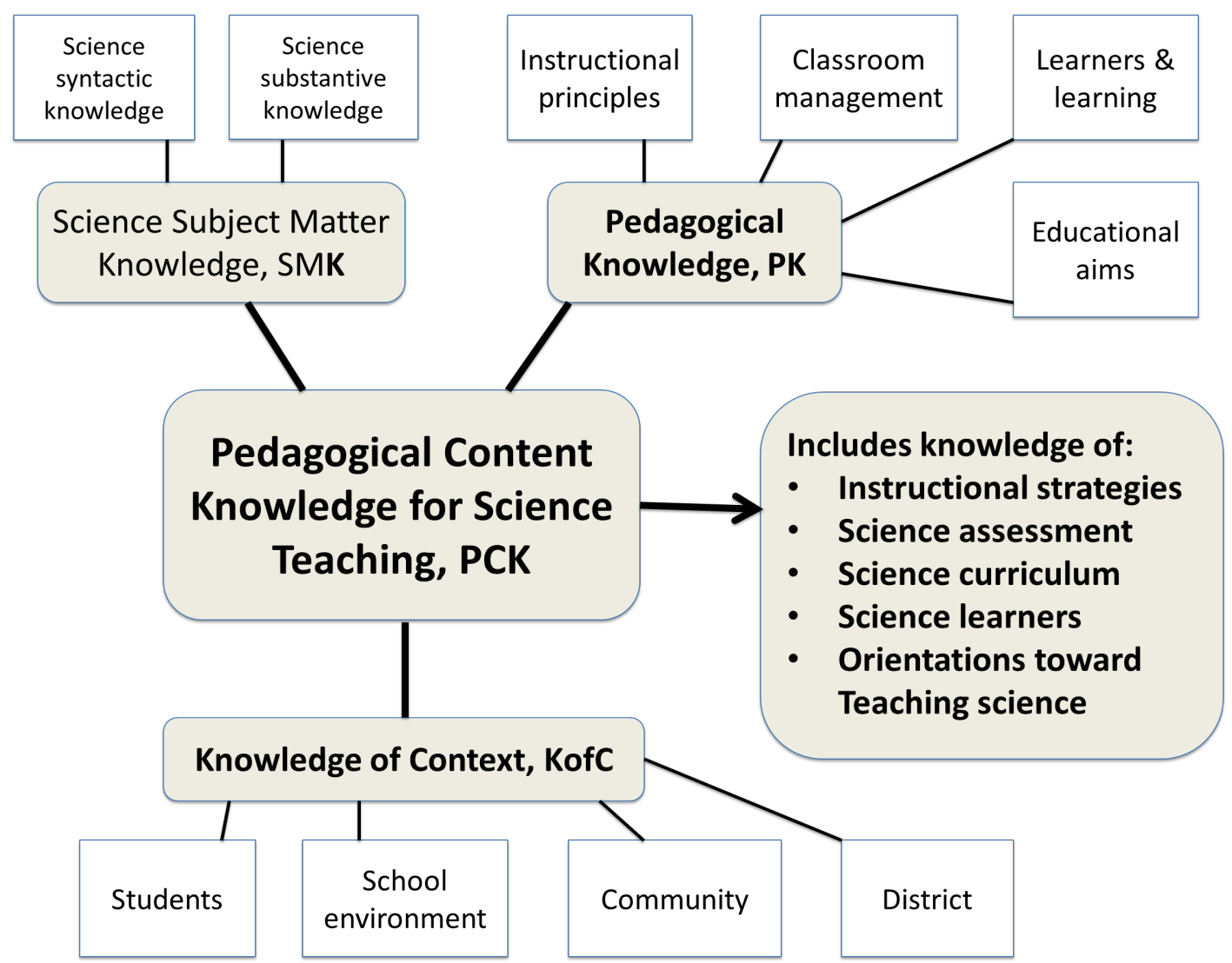

Figur 1 PCK som en lærers specifikke videns og færdighedsdomæne dannet på baggrund af en integration af de tre underkategorier SMK, PK og KofC (frit efter Abell, S. K., 2007). 
Abell (2007) samt Magnusson, Krajcik, \& Korko (1999) forstår således PCK begrebet som den specielle faglighed undervisere besidder, og som med et dansk ord kan kaldes undervisningsfaglighed (Nielsen, 2008; Andersen, 2006). Denne specielle faglighed er således en tæt forbundet integration af underviseres viden og færdighed om relevante forhold omfattende et givent videnskabsfag (SMK), almen og fagdidaktiske forhold (PK) samt om kontekstuelle forhold (KofC). Det er således denne forståelse af PCK begrebet, der anvendes i denne artikel.

Et nyt, større tysk studie baseret på kvantitative studier af matematiklæreres undervisningsfaglighed, viser blandt andet at matematiklærere med en stærk fagfaglig viden (SMK) også udvikler en stærkere undervisningsfaglighed (PCK) i forhold til matematiklærere med en svagere fagfaglig viden (Kleickmann, Richter, Kunter Elsner, Besser, Krauss, \& Baumert, 2013). Det var en bekymring for det manglende fagfaglige fokus i den didaktiske diskurs, som oprindelig fik Shulman til at introducere begrebet Subject Matter Knowledge og Pedagogical Content Knowledge (Shulman, 1986). Dog konkluderede Sandra Abell (2007) i et større review-arbejde, at der ikke er en entydig sammenhæng mellem naturfagslærere SMK og effektive undervisning.

\section{Hypoteser og forskningsspørgsmål}

Geografi kun et lille fag i den danske folkeskole, med det næstmindst samlede antal læste timer, hvilket i 2013 udgjorde i alt 232.590 læste geografitimer (Nikolajsen \& Larsen, 2013). Disse timer var typisk fordelt med 2 timer i 7. klasse, 1 time i 8. klasse og 1 time i 9. klasse. Selvom der de senere år er udkommet en del didaktisk litteratur som omfatter geografi i såvel folkeskolen, gymnasiet og læreruddannelsen (se f.eks.: Møller, 2001; Kristensen \& Laigaard, 2007; Kristensen, Kjeldsen, Pedersen, Jørgensen \& Bruun, 2011; Heer, Dolin, Czeskleba-Dupont, \& Jakobsen, 2002; Ehlers \& Volkers, 2008; Miller, Christensen, Staugaard \& Holm-Larsen, 2009), har skolefaget kun haft ringe forskningsmæssig bevågenhed. Men netop folkeskolen, har i øjeblikket politikernes og mediernes bevågenhed, ikke mindst $\mathrm{i}$ forlængelse at den netop gennemførte folkeskolereform ${ }^{1}$ og nye læreruddannelse $\left(\mathrm{LU}_{13}\right)^{2}$ i Danmark. Således er der kommet mere fokus på lærernes udvikling af deres faglighed, specielt inden for naturfagene, matematik og dansk.

Fra min undervisning i geografi på VIA University College Læreruddannelsen i Aarhus, har jeg gentagne gange oplevet at de lærerstuderende finder stofområdet med vejrets dannelse, klima samt de naturfaglige processer som ligger til grund for klimaændringer, for

\footnotetext{
${ }^{1}$ Se f.eks.: http://www.uvm.dk/Den-nye-folkeskole/Lovgrundlag (11.08.14)

${ }^{2}$ Se f.eks.: http://ufm.dk/lovstof/politiske-aftaler/reform-af-laereruddannelsen eller bekendtgørelsen https://www.retsinformation.dk/Forms/Ro710.aspx?id=145748 (begge: 11.08.14)
} 
begrebstunge og komplekse. Meget sigende er det gerne det stofområde som skal repeteres af underviserne, inden den afsluttende eksamen i faget. Stofområdet omhandlende klimaændringer, hvor menneskets samspil med naturen i højere grad er i centrum i undervisningen, f.eks. i form af analyse af produktions mønstre og forbrugsmønstre som årsag til klimaændringer, finder de lærerstuderende ofte intuitivt lettere. I en undersøgelse vedrørende lærers forståelse af klimaændringer, viste det sig at "... many teachers knew a considerably amount about climate change, but they also had many misconceptions" (Hayhoe, Bullock \& Hayhoe, 2011, 259). Nogle af de misforståelser undersøgelsen nævner er således: "When the polar sea ice floating in the Arctic ocean melts it causes ocean levels to rise. Oceans only absorbs a little of the atmospheric $\mathrm{CO}_{2}$ produced from human activities. Earthquakes and tsunamis are related to global warming.. (Hayhoe, Bullock \& Hayhoe, 2011, s. 258) De naturfaglige stofområder vedrørende klimaændringer kan altså være svære at tilegne sig. Hvorimod de stofområder hvor følgevirkningerne af klimaændringerne påvirker menneskets levevilkår, f.eks. i form af at mennesker i lavtliggende kystregioner må flytte til højere beliggende steder, ofte vil være umiddelbart lettere forståeligt.

Geografilærerne i denne her undersøgelse har generelt en del undervisningserfaring. De fleste af dem er tilknyttet QUEST-projektet ${ }^{3}$, enten som direkte deltagere eller som kollega til andre i skolens naturfaggruppe, der deltager i projektet. På den baggrund er der opstillet følgende to hypoteser og forskningsspørgsmål for vedrørende undersøgelse af geografilæreres undervisningsfaglighed (tabel 1).

Tabel 1 Hypoteser og forskningsspørgsmål

Hypotese 1

Geografilærerne mener at de naturfaglige stofområder vedrørende klimaændringer er begrebstunge og komplekse.

Hypotese 2

Ift. udvikling af deres undervisningsfaglighed, lægger geografilærerne ikke så megen vægt på deres formelle kvalifikationer men derimod egne refleksioner og interaktion med kollegaer.
Forskningsspørgsmål 1

Hvad karakteriserer geografilærernes PCK i forhold til at undervise i vejr og klimaændringer?

Forskningsspørgsmål 2

Hvilke faktorer mener geografilærerne har haft betydning for udviklingen af deres PCK?

\section{Metode}

Forskningsdesignet har udgangspunkt $\mathrm{i}$ at indfange de enkelt personers narrativer, $\mathrm{i}$ forhold til de kontekster, som de har praktiseret og udviklet deres undervisningsfaglighed i. Derfor er der i foråret 2014 indsamlet interviewdata (Cohen, Manion, \& Morrision, 2007; Kvale, 1997) fra 8 geografilærere fordelt på 4 skoler i Region Midtjylland. Skolerne, og dermed de fleste af geografilærerne, har i varierende grad været deltagere i et stor-skala

3 Se f.eks. www.questprojekt.dk (15.01.15) 
skoleudviklingsprojekt, det såkaldte QUEST-projekt, som fokuserer på udvikling af naturfagslærers undervisningsfaglighed (Nielsen, Pontoppidan, Sillasen, Mogensen, \& Nielsen, 2013). Nogle af geografilærerne deltog i kursusaktiviteter mens andre deltog indirekte, i form af aktiviteter på skolen, som var initieret af andre naturfags-kollegaers medvirken i QUEST-projektet. Inden udvælgelsen af skoler og lærere, blev baggrundsmateriale fra QUEST-projektet gennemlæst, således at der søgtes maksimal variation (Flyvbjerg, 2006) blandt geografilærerne ift. alder, køn, anciennitet og uddannelsesbaggrund, samt ift. skolestørrelse (stor/lille) og skolernes geografiske placering (landsby/provinsby/storby) Studiet udgør således et casestudie med mulighed for, at det kan give andre geografilærere nogle narrativer og billeder af praksisser, som de eventuelt kan spejle deres egen undervisningsfaglighed i. Interviewene blev gennemført som semistrukturerede interviews, hvilket: "... har en række temaer, der skal dækkes, såvel som forslag til spørgsmål. Men på samme tid hersker der åbenhed over for ændringer af spørgsmålenes rækkefølge og form, såvel at man kan forfølge de svar, interviewpersonerne giver, og de historier, de fortæller" (Kvale, 1997, s. 129). Den dertil udviklede interviewguide indeholdte fire overordnede svarkategorier: 1) baggrundsoplysninger, 2) forståelse af egen PCK ift. emnet vejrets dannelse og klimaændringer, 3) udvikling af egen PCK ift. emnet vejrets dannelse og klimaændringer, 4) QUEST-projektets betydning for udvikling af egen undervisningsfaglighed (PCK).

Vejr og klima er to forskellige begreber, som qua deres definitioner er tæt forbundet. Vejret kan defineres som: " Tilstanden et bestemt sted i den nedre del af atmosfæren på et bestemt tidspunkt. Vejret - som hele tiden ændrer sig - er sammensat af blandt andet temperatur, tryk, fugtighed, nedbør, skyer, sigtbarhed og vind" (Danmarks Meteologiske Institut, DMI). Hvorimod klimaet kan defineres som: "Det gennemsnitlige vejr på et bestemt sted over et længere tidsrum - meteorologiske set normalt en 30-årig periode. Det danske klima er $i$ øjeblikket defineret som gennemsnittet for perioden 1961-199o" (DMI). Der er derfor forskel mellem en "her-og-nu" beskrivelse af det oplevede vejr, og så klimatiske gennemsnitsbetragtninger over tid, hvor ændringer i klimaet kun langsomt lader sig registrere. Ud fra et didaktisk/undervisningsmæssigt synspunkt fordrer dyberegående undervisning i klimaændringer, herunder årsager og virkninger, en forståelse af vejr og klima. Omvendt kan en case indenfor en central og aktuel klimaproblematik være en motiverende indgangsvinkel for en efterfølgende undervisning af elever inden for vejr og klima - emner inden for den systematiske geografi, som i sig selv kan være både svære og abstrakte for nogle elever og studerende. Da vejr, klima og klimaændringer således er tæt forbundne både i faglig og fagdidaktisk sammenhæng, er der undervejs i interviewene forsøgt afdækket lærernes forståelse af egen undervisningsfaglighed ift. disse begreber.

Interviewene blev gennemført som enkeltinterview med hver geografilærer og efterfølgende transskriberet og sendt tilbage til lærerne, med mulighed for kommentering/rettelser. De transskriberede interview blev derefter gennemlæst og kodet ud fra fokuspunkterne i interviewguiden (Saldaña, 2013). Det er således geografilærernes 
egen forståelse af udviklingen af deres undervisningsfaglighed, samt tolkningen af interviewene, der ligger til grund for datamaterialet. For at gøre begrebet undervisningsfaglighed konkret og operationaliserbart blev der i interviewene spurgt specifikt ind til geografilærernes forståelse af deres egen undervisnings-faglighed i forhold til emnet vejr og klimaforandringer. Epistemologisk set er denne deklarative viden, som geografilærerne giver udtryk for, et perspektiv på at afdække geografilæreres undervisnings-faglighed. Igennem interviewene lader geografilærerne således ofte deres konkrete undervisning være et udtryk for egen undervisningsfaglighed. Et andet perspektiv kunne være at undersøge hvordan geografilærernes undervisningsfaglighed kommer til udtryk i den gennemførte undervisning, hvilket også kan kaldes PCK-in-action (van Driel, Berry, \& Meirink, 2014). Da denne undersøgelse er den første i et længerevarende forskningsprojekt, vil dette perspektiv i forhold til geografilærerne, blive undersøgt nærmere på et senere tidspunkt. I forhold til at undersøge læreres emnespecifikke PCK, påpeger PCK-forskningen et behov for dette (van Driel \& Berry, 2012). Derudover antages læreres PCK at være afhængig af personlige aspekter og konteksten, hvilket også understøttes af forskningen (van Driel, Berry \& Meirink, 2014; Verloop, van Driel \& Meijer, 2001; Veal \& MaKinster, 1999). Emnet vejr og klimaforandring er valgt, da det indeholder klare elementer fra såvel naturgeografien og kulturgeografien, samtidig med at det giver god mening at den didaktiske tilgang både er problemorienteret og fagorienteret.

\section{Danske geografilæreres formelle undervisningskompetencer}

Begrebet undervisningskompetence i et fag, kan opfattes som en formel kompetence erhvervet gennem undervisningsfaget på en læreruddannelse, eller via længere tids undervisningserfaring fra skolen kombineret med et vist omfang af efteruddannelse. Men at en helt nyuddannet geografilærer har en formel kompetence til at undervise i skolefaget geografi, er ikke ensbetydende med at vedkommende har veludviklet PCK. Gennem sit læreruddannelsesforløbet har vedkommende givet vis tilegnet sig de væsentligste dele af relevant SMK og har givet vis også tilegnet sig en del relevant PK. Derimod er det uden tvivl begrænset hvor meget KofC vedkommende har tilegnet sig gennem sine praktikperioder/praksiserfaringer gennem studietiden. Dette selvom undervisningsfag i den danske læreruddannelse, herunder geografi, sigter mod at integrere fagfaglig viden og færdigheder med didaktiske viden og færdigheder samt at inddrage praksisperspektiver undervejs i undervisningsfaget. Netop praksis perspektivet er blevet understreget i den nye læreruddannelse (LU13). Omvendt kan man stille spørgsmålstegn ved, om den erfarne geografilærer, med stor erfaring og viden om kontekstuelle forhold (KofC), men uden det formelle undervisningsfag fra læreruddannelsen, har tilstrækkelig indsigt i videnskabsfaget geografi (SMK) samt fagets mange forskellige fagdidaktiske tilgange (PK). Begrebet undervisningskompetence $\mathrm{i}$ geografi dækker således over mange aspekter af en geografilærers viden og færdighedsområder. 
Tidligere undersøgelser har kortlagt nogle elementer af danske geografilæreres kompetencer, herunder deres formelle kompetencer fra læreruddannelsen. I 2000 udkom Geospørg' 98 undersøgelsen (Jensen, Møller, Nielsen \& Laigaard, 2000), og den er senere fulgt op af undersøgelser fra Uni-C, Styrelsen for It og læring, Undervisningsministeriet i Danmark. Resultatet af disse undersøgelser kan aflæses i tabel 2. Siden Geospørg' 98 undersøgelsen har den undersøgte undervisningskompetence blandt lærere i geografi i folkeskolen, først været stigende i perioden, for derefter at stagnere. Det kan skyldes, at geografifaget var muligt at udtrække til en digital afgangsprøve fra og med folkeskolens afgangsprøve sommeren $2007^{4}$. Således må man antage, at der både fra skoleledelsen og geografilærerne selv, var øget fokus på de formelle fagfaglige og fagdidaktiske kompetencer fra dette tidspunkt. Årsagen til stagnationen i perioden 2009-2013 kan skyldes at skoleledelsen og geografilærerne igen laver en fagfordeling hvor hensynet til at skoleklasserne møder få lærere i de forskellige fag, vejer tungere end et hensyn til at lærerne besidder de nødvendige undervisningskompetencer. En praksis som det skønnes har været gældende på en del danske skoler ${ }^{5}$.

Tabel 2 Tabellen viser det procentvise antal geografilærere i folkeskolen, der underviste i skolefaget geografi på det pågældende tidspunkt, og hvorledes deres kompetencer fordeler sig.

\begin{tabular}{|c|c|c|c|c|}
\hline & Geospørg' 98 & Uni-C 2006 & Uni-C 2009 & Uni-C 2013 \\
\hline $\begin{array}{l}\text { Metodiske } \\
\text { kommentarer: }\end{array}$ & $\begin{array}{l}\text { Svar fra } 224 \\
\text { skoler. } \\
\text { Svar \% = } 66 \% \\
\text { af adspurgte }\end{array}$ & $\begin{array}{l}\text { Stikprøver fra } \\
400 \text { skoler }\end{array}$ & $\begin{array}{l}\text { Besvarelser fra } \\
1.280 \text { skoler. } \\
\text { Svar } \%=84 \% \\
\text { af adspurgte }\end{array}$ & $\begin{array}{l}\text { Besvarelser fra } \\
1.100 \text { folkeskoler. } \\
\text { Svar } \%=91,1 \% \\
\text { af adspurgte }\end{array}$ \\
\hline $\begin{array}{l}\text { Formel } \\
\text { undervisnings- } \\
\text { kompetence, } \\
\text { erhvervet via } \\
\text { undervisningsfaget } \\
\text { geografi fra } \\
\text { læreruddannelsen }\end{array}$ & $34 \%$ & $40 \%$ & $53 \%$ & $51 \%$ \\
\hline $\begin{array}{l}\text { Kompetence } \\
\text { skønnet tilsvarende } \\
\text { undervisnings-fag } \\
\text { via efteruddannelse } \\
\text { og erfaring fra } \\
\text { undervisning }\end{array}$ & - & $22 \%$ & $30 \%$ & $16 \%$ \\
\hline Anden kompetence & - & $38 \%$ & $17 \%$ & $33 \%$ \\
\hline
\end{tabular}

\footnotetext{
4 Det skal påpeges, at en anden årsag til forskellen mellem tallene i Geospørg' 98 undersøgelsen og Uni-C's undersøgelserne kan skyldes forskelle i undersøgelsesmetoder.

5 Der er ikke en samlet opgørelse over, hvor udbredt dette såkaldte "få-lærer-princip" har været i Danmark. I litteraturlisten er der givet 3 eksempler på skoler, hvor dette princip er skrevet ind i skolernes målsætninger.
} 
Hvad den sidste kategori: "Anden kompetence" i tabel 2 dækker over, er ikke beskrevet i litteraturen. Men det kan være kompetencer erhvervet fra andre undervisningsfag (samfundsfag, historie, fysik/kemi, biologi el.lign.) samt en personlig interesse i geografifaget som geografilæreren har. Selvom undervisningskompetencen i faget stadigvæk er beskeden vil den uden tvivl i fremtiden blive forstærket af, at der inden år 2020 skal være en $95 \%$ undervisningsfags dækning i faget. Dette skal ifølge Undervisningsministeriet, i øvrigt også gælde for alle folkeskolens andre fag ${ }^{6}$ !

\section{Resultater}

Udtræk fra de transskriberede og kodede interviews, er for overskuelighedens skyld placeret under hvert forskningsspørgsmål i tabel 3 og tabel 4. De implicerede skoler og geografilærere er anonymiserede, men generelle data om skolerne og personerne kan ses til venstre i tabellerne.

Kommentarer indføjet af forfatteren, er sat i parentes med et $\mathrm{S}$ til sidst.

\section{Diskussion}

Nedenstående diskussion vil først behandle forskningsspørgsmålet omhandlende hvad der karakteriserer geografilærernes forståelse af egen undervisningsfaglighed i forhold til vejr og klimaændringer, og derefter deres refleksioner over, hvad der har haft betydning for udviklingen af deres undervisningsfaglighed som geografilærere.

I forhold til det første forskningsspørgsmål, kan man af geografilærernes udsagn se, at deres opfattelse af egen undervisningsfaglighed varierer meget i forhold til emnet vejr og klimaændringer. Sammenholder man lærernes formelle undervisnings-kvalifikationer med deres udsagn om egen undervisningsfaglighed kan man se, at flere af de lærere som har en udtalt humanistisk profil i deres undervisningsfag fra læreruddannelsen, også udtaler at de har, eller har haft det svært med den naturfaglige del af emnet. F.eks. udtaler Nellie (tabel 3, skole ()): " Jeg synes vejr er - klima derimod! Jeg synes vejr er svært! Det der med højtryk og lavtryk og ... det, det bliver meget abstrakt for børn, og jeg synes egentlig også lidt selv, at der er jeg lidt usikker". Det er desuden tankevækkende at nogle af geografilærerne projicerer deres forståelse (beliefs) af egne fag-faglige styrker/svagheder over på eleverne, således at de tror eleverne f.eks. er fagligt svage inden for de samme emner som de selv, hvilket kan henføres til attribution (Schunk, Meece, \& Pintrich, 2013).

I interviewet giver Karen (tabel 3, skole B) således udtryk for, at det både hende selv og eleverne som mener vejr og klima er et svært stofområde. Hun mener også at hendes elever har samme holdning til "den gammeldags forståelse" som hun selv har (Karen, tabel 3). Om der er en faktisk sammenhæng kan ikke afgøres ud fra den foreliggende empiri, da eleverne ikke er blevet spurgt.

\footnotetext{
${ }^{6}$ Se f.eks.: http://www.uvm.dk/Service/Statistik/Statistik-om-folkeskolen-og-frie-skoler/Statistikom-laerere-i-grundskolen/Kompetencedaekning-i-folkeskolen (31.07.14)
} 
Tabel 3 Forskningsspørgsmål 1: Hvad karakteriserer geografilærernes PCK i forhold til at undervise i vejr og klimaændringer?

\begin{tabular}{|c|c|}
\hline Skole & Larerprofil \\
\hline \multirow[t]{2}{*}{$\begin{array}{l}\text { Skole A, i } \\
\text { mindre by } \\
\text { med ca. } 400 \\
\text { elever fra } 1 .-9 . \\
\text { klasse. }\end{array}$} & $\begin{array}{l}\text { Grethe: lærer med } 30 \text { års } \\
\text { erfaring. Undervisnings-fag i } \\
\text { geografi, idræt og mate- } \\
\text { matik fra lærer- } \\
\text { uddannelsen. }\end{array}$ \\
\hline & $\begin{array}{l}\text { Henrik: lærer med } 7 \text { års } \\
\text { erfaring. Undervisnings-fag i } \\
\text { geografi, idræt, biologi og } \\
\text { dansk fra lærer- } \\
\text { uddannelsen. }\end{array}$ \\
\hline
\end{tabular}

Skole B, i storby med ca. 700 elever fra 1.-9. klasse.

\section{Egen fortolkning}

Grethe har en veludviklet SMK,

PK og KofC, hvor hun viser

tydelige tegn på at fagets begreber, metoder og didaktik er initialiseret.

Veludviklet SMK, PK og KofC, Styrke inden for naturgeografien. Lægger vægt på praktiske forsøg i sin undervisning
Karen: lærer med 13 års erfaring. Undervisnings-fag i natur/ teknik og dansk fra lærer-uddannelsen.

Ingen sammen-hængende forståelse af fagets begreber, processer og metoder. Tilsvarende svag fagdidaktisk indsigt.

Lægger vægten på problemorienteret erfaring. Undervisnings-fag i geografi og samfunds-fag fra lærer-uddannelsen.

\section{Korte eksempler på fra lærerinterviews}

"Men til at begynde med var jeg nødt til virkelig at forberede mig ... lære det her - fuldstændig fä begreber ind under huden. Men nu er det altså sådan at det er kommet mere og mere - at jeg kan slippe og tage nogle ting ind, og man kan jonglere med, når man snakker med eleverne".

"Jeg synes, at undervisningen i vejr og klima, men specielt $i$ vejret er kompleks, og det er også det jeg oplever, at eleverne har sværest ved i geografi..."

S: Hvilke dele af geografien synes du der er spændende og du føler dig sikker i - eventuelt?

K: "Jamen det er - altså det som den gammeldags forståelse med atlas ... altså finde ud af, hvor er vi henne i verden og...rige lande, fattige lande, befolkningstilvækst øh... plantebælter - alt det som jeg selv lærte, da jeg gik i skole. Det synes jeg er vildt spændende og det synes eleverne også! Det er det de forbinder med geografi. Jeg ved godt det indeholder så meget mere men...".

"Nej, jeg synes ikke, jo det (vejr og klimaændringer, S) er svært, men det er samtidig også en af de mere sjove områder kan man sige, fordi der er jo ikke nogen facitliste... Og det er jo værdiladet, hvad synes man hver i sær? Og det er nogle af de diskussioner, jeg synes der er enormt spændende for eleverne at få i gang og kan også mærke, at det synes de faktisk også er interessant. For der er ikke en facitliste".

"... Jeg synes, at det er blevet mindre disciplinundervisning, altså hvad hedder sådan noget, det hedder vel fagfaglig undervisning, hvor det handler mere om i dag synes jeg, undervisningen skal være brugbar for eleven".

"... Jeg synes vejr er svært! Det der med højtryk og lavtryk og .. det, det bliver meget abstrakt for børn, og jeg synes egentlig også lidt selv, at der er jeg lidt usikker. Det synes jeg nok er det sværeste inden for det emne".

"Jeg synes det har udviklet sig til at det bliver mere alsidigt faget. ...at det ikke kun er ud fra bogen af. ... at lave nogle små forsøg.... hvis vi har en mulighed for at komme ud... Og så også måske, mere fokus på, at når så eleverne er i gang, at der også er nogle elevprodukter i gang der kan understotte den her viden. Det tænker jeg i hvert fald har udviklet sig, fra $i$ starten, hvor jeg tænker - der var det bare bog og opgaver.

Annette: lærer med 6 års erfaring. Undervisnings-fag i geografi, dansk, engelsk, håndarbejde fra

læreruddannel-sen + BA i antropologi.

Skole D, i mindre by med ca. 300 elever fra 1.-9. klasse.
Rasmus: lærer med 13 års erfaring. Undervisnings-fag i fysik/ kemi og biologi fra læreruddannel-sen.

Michael: lærer med 5 års erfaring. Under-visnings-fag i geografi og fysik/kemi fra lærer-uddannelsen.
Har en humanistiske baggrund men er i gang med at udvikle sin naturfaglige viden og færdigheder. Stærk SMK indenfor kulturgeografien.

Veludviklet SMK med en styrke inden for det naturfaglige område. Stærk PK som stadigvæk udvikles med kollega. Lægger vægt på at inddrage praktisk arbejde $\mathrm{i}$ undervisningen.

Har en meget stærk SMK og PK, og er personlig interesseret i klimaproblematik-ker.
"Men jeg kan godt mærke, at jo mere ... jo mere erfaring jeg fär, jo mere synes jeg også, at den naturgeografiske del, den kommer til at fylde og interessere mig. Jeg tror det har noget at gøre med, med at man, man fär mere viden og man bliver mere sikker $i$ sin viden".

"Altså klimaændringer i geografi kan man næsten ikke, jeg synes ikke, at man kan undervise i klimaændringer i geografi uden samtidig og have nogle tråde i biologi og fysik/kemi”.

"Men hands-on ting synes jeg er vigtigt. Jo mere vi kan, jo mere eleverne de kan bygge ting eller ligge mærke til ting, hvad det så end er, så, så tror jeg det vil have, eller så tror jeg det har en rigtig god effekt på deres forståelse".

"...det er nok det område (klimaændringer, S) at jeg har mest interesse. Altså, det er jo nok der jeg synes, at det er det mest spændende område inden for geografi..."

"...altså til eksamen (geografi på læreruddannelse, S), der var jeg oppe $i$ klimaændringer og det faldt jo lige til højrebenet, fordi det var jo det jeg syntes var spændende...” 
Tabel 4 Forskningsspørgsmål 2: Hvilke faktorer mener geografilærerne har haft betydning for udviklingen af deres PCK?

\begin{tabular}{|c|c|c|c|}
\hline Skole & Lærerprofil & Egen fortolkning & Korte eksempler fra lærerinterviews \\
\hline \multirow[t]{2}{*}{$\begin{array}{l}\text { Skole A, i } \\
\text { mindre by } \\
\text { med ca. } 400 \\
\text { elever fra 1.- } \\
\text { 9. klasse. }\end{array}$} & $\begin{array}{l}\text { Grethe: lærer med } \\
\text { 30 års erfaring. } \\
\text { Undervisnings-fag i } \\
\text { geografi, idræt og } \\
\text { mate-matik fra } \\
\text { læreruddannel-sen. }\end{array}$ & $\begin{array}{l}\text { Som meget erfaren lærer tog } \\
\text { Grethe geografi som et ekstra fag, } \\
\text { hvorfor undervisningen på } \\
\text { læreruddannelsen har betydet } \\
\text { meget for udviklingen af hendes } \\
\text { PCK i faget. }\end{array}$ & $\begin{array}{l}\text { ”... det er nok min undervisning på seminariet [..]Jeg fik } \\
\text { en kæmpe viden [... jeg mødte op hver gang! Og det er } \\
\text { vigtigt. Det er vigtigt for mig, for så får man jo altså } \\
\text { kontinuitet på seminariet (læreruddannelsen, S) - så får } \\
\text { man det ind, hører diskussionerne, bruger noget af det vi } \\
\text { laver". }\end{array}$ \\
\hline & $\begin{array}{l}\text { Henrik: lærer med } 7 \\
\text { års erfaring. } \\
\text { Undervisnings-fag i } \\
\text { geografi, idræt, } \\
\text { biologi og dansk fra } \\
\text { lærer-uddannelsen. }\end{array}$ & $\begin{array}{l}\text { Den kollegiale sparring er vigtig } \\
\text { for udviklingen af Henriks PCK. } \\
\text { Andet -steds nævnes også QUEST- } \\
\text { projektet som værende } \\
\text { betydningsfuldt }\end{array}$ & $\begin{array}{l}\text { ”... når vi sidder på årgangsteamet [..] når vi laver } \\
\text { ideudveksling, til, hvad er det for nogle overordnede } \\
\text { emner vi skal køre næste år [...] det med at sidde og } \\
\text { planlægge undervisning sammen, det betyder rigtig } \\
\text { meget. Det øger da helt klart min faglighed, og så øger det } \\
\text { elevernes udbytte". }\end{array}$ \\
\hline \multirow[t]{2}{*}{$\begin{array}{l}\text { Skole B, i } \\
\text { storby med } \\
\text { ca. } 700 \\
\text { elever fra 1.- } \\
\text { 9. klasse. }\end{array}$} & $\begin{array}{l}\text { Karen: lærer med } 13 \\
\text { års erfaring. } \\
\text { Undervisnings-fag i } \\
\text { natur/-teknik og } \\
\text { dansk fra } \\
\text { læreruddannel-sen. }\end{array}$ & $\begin{array}{l}\text { Næsten intet kollegialt samarbejde } \\
\text { på skolen, hvorfor deltagelse i } \\
\text { QUEST-projektet har været en } \\
\text { øjenåbner. Meget begrænset faglig } \\
\text { udvikling. }\end{array}$ & $\begin{array}{l}\text { "... selvom jeg har været sådan lidt "on-and-off" på det } \\
\text { QUEST, men det har nok været en øh... en øjenåbner, } \\
\text { fordi at du møder kollegaer fra andre fag". }\end{array}$ \\
\hline & $\begin{array}{l}\text { Erik: lærer med } 13 \\
\text { års erfaring. } \\
\text { Undervisnings-fag i } \\
\text { geografi og } \\
\text { samfunds-fag fra } \\
\text { lærer-uddannelsen. }\end{array}$ & $\begin{array}{l}\text { Den personlige interesse i } \\
\text { forskellige aspekter af faget er } \\
\text { drivkraft i hans faglige udvikling, } \\
\text { samt besøg af lærer- } \\
\text { studerende i praktik. }\end{array}$ & $\begin{array}{l}\text { ”... i forhold til geografi er det jo det, jeg selv brænder for, } \\
\text { altså det jeg synes er enormt fascinerende, altså jeg kunne } \\
\text { næsten få lyst til at tage til Island, da der var } \\
\text { vulkanudbrud under isen for at se vandet fosse ud! [..] jo, } \\
\text { jeg mangler faktisk at sige praktikanter". }\end{array}$ \\
\hline \multirow[t]{2}{*}{$\begin{array}{l}\text { Skole C, i } \\
\text { større } \\
\text { provins-by } \\
\text { med ca. } \\
\text { 1.ooo elever } \\
\text { fra 1.-9. } \\
\text { klasse. }\end{array}$} & $\begin{array}{l}\text { Nellie: lærer med } 13 \\
\text { års erfaring. } \\
\text { Undervisningsfag i } \\
\text { geografi, dansk, } \\
\text { natur/ teknik og } \\
\text { idræt fra } \\
\text { læreruddan-nelsen. }\end{array}$ & $\begin{array}{l}\text { Selvrefleksion ift. hendes egen } \\
\text { undervisning og elevernes } \\
\text { respons, har haft størst betydning } \\
\text { for udvikling af Nellies PCK. }\end{array}$ & $\begin{array}{l}\text { "Jamen, det tror jeg faktisk har været mig selv og } \\
\text { eleverne simpelthen. Hele tiden finde ud af, ok- } \text { er det for } \\
\text { højt det her, jeg skal have det længere ned på niveau. Og } \\
\text { så samspillet med kollegaerne". }\end{array}$ \\
\hline & $\begin{array}{l}\text { Annette: lærer med } \\
6 \text { års erfaring. } \\
\text { Undervisnings-fag i } \\
\text { geografi, dansk, } \\
\text { engelsk, } \\
\text { håndarbejde fra } \\
\text { lærer-uddannelsen + } \\
\text { BA i antropologi. }\end{array}$ & $\begin{array}{l}\text { Annette er relativt nyuddannet } \\
\text { lærer, og referer ligesom Grethe til } \\
\text { undervis-ningen på lærerud- } \\
\text { dannelsen, som betydningsfuld for } \\
\text { hendes udvikling af PCK. } \\
\text { Derudover nævnes kollegaerne i } \\
\text { geografi. }\end{array}$ & $\begin{array}{l}\text { "... hans undervisning (hendes geografi-underviser fra } \\
\text { læreruddannelsen, S) passede til mig. Jeg synes det var, } \\
\text { jeg synes det var rigtig godt [... også de faglige samtaler } \\
\text { med andre geografilærere tror jeg, hvor man bekræfter } \\
\text { hinanden i, hvorfor er det det her det er spændende og } \\
\text { nej, og du er mest til naturdelen og jeg er til kulturdelen } \\
\text { og ... man kunne jo godt gå ind sådan låne hinanden..... }\end{array}$ \\
\hline \multirow{4}{*}{$\begin{array}{l}\text { Skole D, i } \\
\text { mindre by } \\
\text { med ca. } 300 \\
\text { elever fra 1.- } \\
\text { 9. klasse. }\end{array}$} & $\begin{array}{l}\text { Rasmus: lærer med } \\
13 \text { års erfaring. } \\
\text { Undervisnings-fag i }\end{array}$ & $\begin{array}{l}\text { Rasmus er en erfaren lærer, som } \\
\text { sammen med sin fortrolige } \\
\text { kollegaer Michael, udvikler sin }\end{array}$ & $\begin{array}{l}\text { "Han (kollegaen Micheal, S) og jeg underviser i alle tre fag } \\
\text { i udskolingen [..] konstant, formelt eller uformelt, stikker } \\
\text { hovederne sammen og udveksler idéer og videns deler. }\end{array}$ \\
\hline & & & $\begin{array}{l}\text { "Det kræver en fortrolighed [...] det tror jeg simpelthen vi } \\
\text { er blevet uddannet i [...] også igennem QUEST faktisk". }\end{array}$ \\
\hline & læreruddannel-sen. & $\begin{array}{l}\text { fora, som f.eks. i QUEST sammen- } \\
\text { hænge, men også i uformelle } \\
\text { sammen-hænge, hvor den } \\
\text { personlige kemi spiller en } \\
\text { betydelig rolle. }\end{array}$ & $\begin{array}{l}\text { S: Men det er vel også noget med, at man falder i hak } \\
\text { sammen, altså der er en personlig faktor eller hvordan? } \\
\text { ”... vi taler jo også om alle mulige andre ting. Og laver } \\
\text { mange ting og synes det er rigtigt sjovt at finde på nye } \\
\text { ting som man præsenterer for hinanden". }\end{array}$ \\
\hline & $\begin{array}{l}\text { Michael: lærer med } \\
5 \text { års erfaring. } \\
\text { Undervisnings-fag i } \\
\text { geografi og } \\
\text { fysik/kemi fra } \\
\text { læreruddannel-sen. }\end{array}$ & $\begin{array}{l}\text { Han har kontinuerligt udviklet sin } \\
\text { PCK i forskellige sammenhænge. } \\
\text { Samarbejdet med sin fortrolige } \\
\text { kollega Rasmus, har stor } \\
\text { betydning både for hans faglige } \\
\text { udvikling og personlige } \\
\text { arbejdsglæde. }\end{array}$ & $\begin{array}{l}\text { "...så har jeg en god kollega (Rasmus, S) [..] deler } \\
\text { naturfagene i overbygning ... vi har meget sparring } \\
\text { [..]ikke bare [..]møder [..] när vi [..]spiser frokost } \\
\text { [..]altid!" [..]tit nemmest at fă ideer gennem andre". } \\
\text { S: Er det med til at skabe en større arbejdsglæde? } \\
\text { "Det er det. Helt klart!"."Jeg har holdt nogle foredrag for } \\
\text { [..]seniorklub herude [..]der lig-ger mange timers arbejde } \\
\text { i [...]man har fäet noget viden inden for nogle emner, helt } \\
\text { dybden". } \\
\text { "... det man har med fra læreruddannelsen, det tæenker } \\
\text { man jo nok mere sådan - det ligger sådan implicit i’en". }\end{array}$ \\
\hline
\end{tabular}


I undersøgelsen er der to lærere som ikke er uddannet i undervisningsfaget geografi fra læreruddannelsen, nemlig Karen og Rasmus. Den ene (Karen, tabel 3, skole B) giver klart udtryk for manglende Subject Matter Knowledge samt et fagsyn som tager udgangspunkt i egen oplevet undervisning fra folkeskolen. Den anden (Rasmus, tabel 3, skole D) giver derimod udtryk for et stort fagligt overskud, og han kan sagtens koble emnet vejr og klimaændringer til de andre naturfag, samt inddrage elevundersøgelser i undervisningen. Rasmus har en dybere forståelse for naturfagene, sikkert fordi han både har taget undervisningsfagene fysik/kemi og biologi på læreruddannelsen.

I forhold til forskningsspørgsmål 2, er der flere af geografilærerne som giver et billede af en undervisningsfaglighed, der er udviklet over tid (Nellie, Annette, Rasmus med flere, tabel 4), i samarbejde med kollegaer og refleksion over egen praksis. De giver udtryk for at udvikle sig fra den usikre novice, hvor undervisningen nøje holder sig til curriculum og det givne undervisningsmateriale, til eksperten der føler sig fagligt sikker og som i den givne situation intuitivt vælger mellem flere muligheder. Dette kommer blandt andet til udtryk hos den meget erfarne lærer Grethe (tabel 4, skole A): "... kan slippe og tage nogle ting ind, og man kan jonglere med, når man snakker med eleverne" (Grethe). Henrik fra samme skole (tabel 4, skole A) udtrykker også denne dybe faglighed på følgende måde: "I starten tænkte jeg meget på - nu skal jeg nå alle de her mål i faghæftet. Det skænker jeg nærmest ikke en tanke mere... at når man har overskud og kan gøre mange forskellige ting, ...”. Disse beskrivelser af egen undervisningsfaglighed stemmer godt overens med Dreyfus' beskrivelse af eksperten, som en person der: "...not only sees what needs to be achieved; thanks to his or her vast repertiore of situational discriminations, he or she also sees immediately how to achieve this goal" (Dreyfus, 2004, 179-180). Vigtigheden af den kollegiale sparring for læreres faglige udvikling, i form af aktiv deltagelse i læringsfællesskaber påpeges af flere forskere (f.eks. Hargreaves \& Fullan, 2012; MacLaughlin \& Talbert, 2006), og er også et fokuspunkter i QUEST-projektet. Det er dog ikke alle lærere som opnår en veludviklet undervisningsfaglighed på ekspert-stadiet måske på grund af manglende Subject Matter Knowledge (SMK).

Vægtigheden af et tæt kollegialt samarbejde som grundlag for udvikling af ens professionalitet, findes især udtalt mellem Rasmus og Michael (tabel 4, skole D). De udtaler, at møder forgår på såvel det formelle plan (f.eks. i naturfagsteam) som det uformelle plan (f.eks. i pauser). Det bliver implicit udtalt i begge interviews, at det gode professionelle samarbejde også beror på andet og mere end blot en fælles interesse for naturfag, men også at der en personlig sympati mellem lærerne - man kan kalde det en god personlig kemi mellem dem.

Flere af de interviewede geografilærere giver også udtryk for en stærk personlig interesse i enten kulturgeografiske eller naturgeografiske emner, hvor denne interesse har givet dem en lyst til at vælge geografi som undervisningsfag. For eksempel er Erik (tabel 4, skole B) meget optaget af spektakulære naturgeografiske fænomener, og udtrykker: "det, jeg selv brænder for, altså det jeg synes er enormt fascinerende, altså jeg kunne næsten få 
lyst til at tage til Island, da der var vulkanudbrud under isen for at se vandet fosse ud...", hvor han andetsteds i interviewet også siger at han tager sådanne spektakulære begivenheder ind i undervisningen og fagliggøre dem. Den personlige interesse overlapper således det professionelle lærerperspektiv, og kan ses som grundlag for at udvikle ens faglighed. Det tyder altså på at lærernes personlige interesse for enten natur- eller kulturgeografien, også har haft betydning for udviklingen af deres undervisningsfaglighed. Erik nævner desuden, som den eneste af geografilærerne, at praktikanter fra læreruddannelsen er med til at udvikle hans undervisningsfaglighed. I forskningslitteraturen er det dog ofte det forhold, at skolepraktikerfaringer i et givent (natur)fag, kan have været med til at udvikle lærerstuderendes PCK, som bliver undersøgt (Kleickmann, et al, 2013; Mulholland, \& Wallace, 2005; Tamir, 1988). Det omvendte forhold, hvorledes lærerstuderende gennem deres praktik kan have været med til at udvikle den erfarne lærers PCK, har der ikke været fokus på inden for PCK-forskningen.

Geografilærerne Erik og Michael har to forskellige fag-faglige baggrunde. Erik, der har en samfundsfaglig baggrund og også interesserer sig for såkaldte kreative fag, lægger ifølge eget udsagn megen vægt på en problemorienteret og diskuterende undervisning. Michael, der har en naturvidenskabelig baggrund og altid har interesseret sig for naturfag, lægger, ifølge ham selv, vægt på fagets samspil med de andre naturfag i udskolingen (7.-9. klasse). Den fag-faglige baggrund (SMK) og personlige interesse, afspejles altså, ifølge lærerne selv, i deres undervisning (PCK in-action). Om det så faktisk er tilfældet, kræver observationer i klasselokalet af den gennemførte geografiundervisning. Dette er et forskningsspor, som er intentionen at forfølge fremover i forskningsprojektet.

\section{Konklusion}

Dette mindre studie har forsøgt at klarlægge 8 geografilæreres forståelse af, hvad der karakteriseres deres egen undervisningsfaglighed, forstået som PCK ift. vejr og klimaændringer, og hvad der har været medvirkende årsag til udviklingen af deres undervisningsfaglighed. Resultaterne fra de 8 semi-strukturerede interviews, indikerer at der en markant forskel mellem lærernes forståelse af egen undervisningsfaglighed, som bl.a. afhænger af deres faglige baggrund og interesse. Således lægger lærerne med en relativ stærk faglig profil inden for naturfagene, mere vægt på at undervise i både vejr, klima og klimaændringer samt at integrere denne undervisning med anden naturfags-undervisning. Hvorimod lærerne med en relativ stærk faglig profil inden for samfundsfag og humaniora ikke lægger så megen vægt på undervisningen i vejr og klima, men mere på en diskursiv problemorienteret undervisning inden for klimaændringer gerne i sammenhæng med f.eks. samfundsfag.

De 5 interviewede geografilærere som har været aktive deltagere i QUEST-projektet, påpeger at deltagelsen i projektet har været med til at udvikle deres undervisningsfaglighed, f.eks. i form af konkrete arbejdsmetoder eller at det har været fremmende for det kollegiale samarbejde og derved deres undervisningsfaglighed. Ikke overraskende viser det sig også, 
at den personlige relation mellem naturfagskollegaer er af stor betydning for det indbyrdes samarbejde. Flere af geografilærerne påpeger også den personlige interesse i forskellige dele af faget, som værende en årsag til at udvikle sig fagfagligt. Desuden er der en af lærerne som påpeger at lærerstuderende i praktik i geografi der hele tiden stiller spørgsmål til vedkommendes, er med til at udvikle vedkommendes undervisningsfaglighed.

\section{References}

Abell, S.K., (2007). Research on science teacher knowledge. In S.K. Abell \& N.G. Lederman (Eds.), Handbook of research on science education (pp. 1105-1149). Mahwah, NJ: Lawrence Erlbaum Associates.

Andersen, A. M., (2006). Undervisningsfaglighed - hvad en underviser bør vide. MONA, 2006-4, 7075 .

Cochran, K. F., King, R. A., \& DeRuiter, J. A. (1991). Pedagogical content knowledge: A tentative model for teacher preparation. Paper presented at the annual meeting of the American Educational Research Association, Chicago, April 1991.

Cohen, L., Manion, L., \& Morrison, K. (2007). Research Methods in Education. London: Routledge.

Dreyfus, S. E. (2004). The Five-Stage model of Adult Skill Acquisition. Bulletin of Science, Technology \& Society, 24(3), 177-181.

Van Driel, J. H., Berry, A., \& Meirink, J. (2014). Research on Science Teacher Knowledge. In J. J. Loughran (Section Eds.), Handbook of Research on Science Teacher Knowledge Volume II, (pp. 848-870). New York: Routledge.

Van Driel, J. \& Berry, A. (2012). Teachers Professional Development Focusing on Pedagogical Content Knowledge. Educational Researcher, 41(1), 26-28.

Ehlers, P. \& Volkers, G. (Eds.) (2008). Geofaglighed som kompetencer. Brønshøj: Forlaget Tunet.

Flyvbjerg, B. (2006). Five Misunderstandings About Case-Study Research. Qualitative Inquiry. 12(2), 219-245.

Grossman, P. L. (1990). The making of a teacher: Teacher knowledge and teacher education. New York: Teachers College Press.

Hargreaves, A. \& Fullan, M. (2012). Professional Capital: Transforming Teaching in Every School. New York Columbia University: Teachers College Press.

Hayhoe, D., Bullock, S., and Hayhoe, K. (2011). A Kaleidoscope of Understanding: Comparing Real with Random Data, Using Binary-Choice Items, to Study Preservice Elementary Teachers' Knowledge of Climate Change. Weather, Climate, and Society 3(4), 254-260.

Heer, G., Dolin, J., Czeskleba-Dupont, S., \& Jakobsen, L. (Eds.) (2002). Geografididaktik - bidrag til debat. Brenderup: Geografforlaget.

Jensen, M. L., Møller, J, P, Nielsen, K, \& Laigaard, B, (2000). Geospørg '98 En spørgeskemaundersøgelse af geografiundervisningen i folkeskolen 1998/98, Brenderup: Geografforlaget.

Kleickmann, T., Richter, D., Kunter, M., Elsner, J., Besser, M., Krauss, S., \& Baumert, J., (2013). Teachers' Content Knowledge and Pedagogical Content Knowledge: The Role of Structural Differences in Teacher Education. Journal of Teacher Education. 64(1), 90-106.

Kristensen, P., Kjeldsen, N., Pedersen, O., Jørgensen, H. L., \& Bruun, K., (2011). Geografi undervisning Fagdidaktisk grundbog, Geografforlaget.

Kristensen, P. og Laigaard, B. (Eds.) (2007). Feltgeografi, Geografforlaget.

Kvale S. (1997). InterView En introduktion til det kvalitative forskningsinterview. København: Hans Reitzels Forlag. 
Magnusson, S., Krajcik, J., \& Borko, H. (1999). Nature, sources and development of pedagogical content knowledge for science teaching. In J. Gess-Newsome \& N. G. Ledermann (Eds.), Examining pedagogical content knowledge: The construct and its implications for science education, pp. 95-132. Boston: Kluwer.

McLaughlin, M. W. \& Talbert J. E. (2006). Building School-Based Teacher Learning Communities. New York: Teachers College Press.

Miller, T., Christensen, B., Staugaard, H. J., \& Holm-Larsen, S. (Eds.) (2009). Evaluering og test $i$ geografi. Frederikshavn: Dafolo.

Mulholland, J. \& Wallace, J. (2005). Growing the Tree of Teacher knowledge: Ten Years of Learning to Teach Elementary Science. Journal of Research in Science Teaching, 42(7), 767-790.

Møller, J. P. (2001). Omverdensforståelse Didaktiske perspektiver og eksempler. Aarhus: Klim.

Nielsen, B. L., Pontoppidan, B., Sillasen, M., Mogensen, A. \& Nielsen, K., (2013). QUEST - et storskalaprojekt til udvikling af naturfagsundervisning. MONA, 2013-3, 49-66.

Nielsen, B. L., (2008). Læreruddannelse, naturfag og PCK. MONA, 2008-4, 75-78.

Nikolajsen, L. S. \& Larsen, T. (2013). Kortlægning af linjefagsdækning ifolkeskolen 2013 Bilagsnotat. Copenhagen: Uni-C, Undervisningsministeriet.

Saldaña, J. (2013). The Coding Manual for Qualitative Researchers. Washington DC: SAGE.

Shulman, L. S. (1986). Those who understand: Knowledge growth in teaching. Educational Researcher, 15(2), 4-14.

Schunk, D. H., Meece, J. R. \& Pintrich, P. R., (2013). Motivation in Education:Theory, Research, and Applications. Boston: Pearson (4th Ed.).

Tamir, P. (1988). Subject Matter and related pedagogical knowledge in teacher education. Teaching \& Teacher Education, 4(2), 99-110.

Veal, W. R \& MaKinster, J. G. (1999). Pedagogical Content Knowledge Taxonomies. Electronic Journal of Science Education, 3(4).

Verloop, N., van Driel, J., \& Meijer, P. (2001). Teacher knowledge and the knowledge base of teaching. International Journal of Educational Research, 35(5), 441-461. 